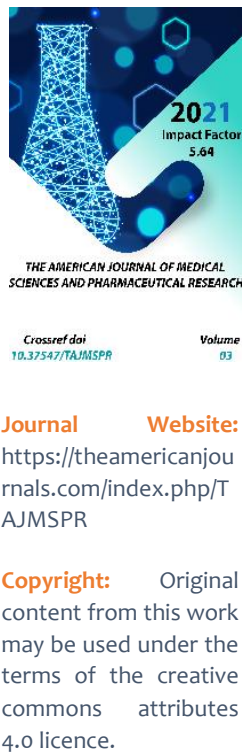

\title{
Dangerous Symptoms Of Covid-19 Virus And Analysis Of Their Characteristics
}

\author{
A.B. Tleubergenova \\ Karakalpak Medical Institute, Uzbekistan \\ Z.U. Kunnazarova \\ Karakalpak Medical Institute, Uzbekistan
}

\section{ABSTRACT}

COVID-19, like other respiratory viruses, has extrapulmonary manifestations. In particular, exposure to the virus leads to damage to the cardiovascular system (CVS). The review presents the current problems of the combination of the new coronavirus infection COVID-19 and cardiovascular diseases. The results of a few clinical studies and individual clinical cases, illustrating the difficulties of managing patients with viral infection and comorbidities, are discussed. The combination of COVID-19 with cardiovascular diseases creates additional difficulties in diagnostics, determining priority tactics, changing the routing orders of patients with emergencies, and choosing therapy.

\section{KEYWORDS}

COVID-19, heart disease, risk factors, ARDS.

\section{INTRODUCTION}

In connection with the increase in new cases of COVID-19 in Uzbekistan, the Ministry of Health of the Republic set goals for health professionals related to the rapid diagnosis and provision of medical care to patients. Currently, an intensive study of the clinical and epidemiological characteristics of the disease continues, the development of new means of its prevention and treatment, which are the main areas of study of this disease. [1] Coronavirus Disease 2019 (COVID-19) has caused significant morbidity and mortality worldwide since December 2019. [12] The 2019 Coronavirus Disease (COVID-19) outbreak has become a major public health threat around the world, as it has a high infectiousness and various mortality rates $[5,16]$. 
The most common clinical manifestation of a new variant of coronavirus infection is bilateral pneumonia (viral diffuse alveolar injury with microangiopathy), in 3-4\% of patients the development of acute respiratory distress syndrome was recorded. Starting from May 2021, daily new cases of COVID-19 began to fluctuate from 300 to 400 cases per day (Uzbek newspaper). In some patients, hypercoagulable syndrome with thrombosis and thromboembolism develops, other organs and systems are also affected (central nervous system, myocardium, kidneys, liver, gastrointestinal tract, endocrine and immune systems), and sepsis and septic shock may develop [1].

According to the Ministry of Health of the Republic of Uzbekistan. the epidemiological situation in the world continues to be alarming. The total number of infected has exceeded 170 million, having increased only in the last 3.5 days by 1 million. The main foci of infection are still the United States, Brazil and India. North America accounts for over 6.1 million cases ( $30.5 \%$ of the total). In Asia, this figure is almost 5.1 million (25.1\%), South America - more than 4.75 million (23.4\%). The European Region accounts for $16 \%$ of global COVID-19 cases and $25 \%$ of deaths. According to WHO, the countries reporting the highest mortality rates are India (currently 400,000), Brazil $(357,000$ population). Therefore, the urgent task of world specialists is to study the morbidity and mortality from this disease [3.22].

According to Huang Q's research, the total study population included 416 patients hospitalized with confirmed COVID-19: 82 patients (19.7\%) with heart damage and 334 patients (80.3\%) without heart damage. The average age was 64 years (from 21 to 95 years), $211(50.7 \%)$ were women. Among these study patients, fever was the most common symptom (334 patients [80.3\%]). Cough, shortness of breath, fatigue, sputum production and muscle pain were observed in 144 patients (34.6\%), 117 patients (28.1\%), 55 patients (13.2\%), 23 patients (5.5\%) and 19 patients (4.6\%). \%), respectively. Diarrhea (16 patients [3.8\%]), chest pain (14 patients [3.4\%]), sore throat (12 patients [2.9\%]), rhinorrhea (10 patients [2.4\%] ) and headache (9 patients [2.2\%]]) were rare. Hypertension (127 patients [30.5\%]) and diabetes (60 patients [14.4\%]) were the most common comorbid conditions. Of these 416 patients, 44 (10.6\%) and 22 (5.3\%) suffered from coronary artery disease and cerebrovascular disease, respectively. The proportion of chronic heart failure, chronic renal failure, chronic obstructive pulmonary disease, cancer, pregnancy and hepatitis B infection was $4.1 \%$ (17 patients), 3.4\% (14 patients), 2.9\% (12 patients), 2 , 2\% (9 patients). patients), $1.7 \%$ (7 patients) and 1.0\% (4 patients), respectively. All patients underwent laboratory and X-ray examinations, as well as ECG after admission [12].

Also, a study by the Chinese specialists Shaobo Shi and other associations of cardiac pathology and mortality indicated that patients with heart disease compared with patients without heart damage had a shorter duration from the onset of symptoms to follow-up. [12] Mortality was higher among patients with heart disease.

Adjusted for age, pre-existing cardiovascular disease (hypertension, coronary heart disease, and chronic heart failure), cerebrovascular disease, diabetes mellitus, chronic obstructive pulmonary disease, renal failure, cancer, ARDS showed a significantly higher risk of death in patients with heart disease. lesion than in patients without heart disease, or during the time from the onset of symptoms or the time 
from admission to the endpoint of the study. [2.12].

This study demonstrates a statistically significant association between heart damage and mortality in COVID-19 patients. Heart disease, a common complication (19.7\%), was associated with an unexpectedly high risk of death during hospitalization [12].

In other studies by scientists, cardiovascular complications of COVID-19 in 121 patients, cases of hypertension occurred in 61 patients $(50.4 \%)$ in the hospital. Of these patients, $71.9 \%$ developed persistent tachycardia, including $40 \%$ with ongoing tachycardia during outpatient follow-up [5.15].

In addition, preexisting cardiovascular disease may also be more susceptible to heart damage caused by COVID-19, as approximately $30 \%$ and $60 \%$ of the patients with heart damage in the present study had a history of coronary artery disease and hypertension, respectively, which were much lower. more often than those who did not have heart disease. Likewise, in a recent report, $25 \%$ and $58.3 \%$ of critically ill patients with COVID-19 had underlying heart disease and hypertension, respectively [7.8].

And also analyzed the studies of such authors as Ranieri, Yu CM, Wong RS on the risk factors for the development of ARDS (Acute Respiratory Distress Syndrome) in COVID-19. [6.14]

In numerous studies by European and Chinese scientists, the risk factors for ARDS are advanced age, especially after 65 years of age and older, gender differences did not have significant values, by ethnicity, African Americans are at a higher risk of developing ARDS than white Americans. Also, comorbid conditions such as hypertension, diabetes mellitus, COPD, obstructive sleep apnea syndrome, bronchial asthma and "other pulmonary diseases" have been associated with an increased risk of ARDS. Three studies have examined the effect of BMI on ARDS risk, with conflicting results. Patients with heart disease are a higher risk factor for the development of ARDS [6.14].

In terms of laboratory data, patients with cardiac disease compared with patients without cardiac disease showed higher mean leukocyte count, levels of C-reactive protein, procalcitonin, $\mathrm{CPK}-\mathrm{MB}$, methemoglobin, pro-Btype $\mathrm{N}$-terminal natriuretic peptide, aspartate aminotransferase and creatinine during hospitalization, but lower average lymphocyte count. In terms of radiographic findings, bilateral pneumonia (75 of 82 patients [91.5\%] and multiple spotting and ground glass symptom (53 [64.6\%])) were more pronounced, more prevalent in patients with heart disease than in patients without heart disease pathology $[12,13]$.

The ratio of risks to the risk of developing ARDS, presented by scientists, depending on the results of individual laboratory studies, shows that a high level of CRP, LDH, D-dimer has a higher risk for a severe course of this disease.

In treatment, compared with patients without heart disease, patients with heart disease required more non-invasive ventilation ( 38 [46.3\%] versus 13 [3.9\%] and invasive mechanical ventilation (18 [22.0\%] versus 14 [4 , $2 \%]$ ); The use of antibiotics (68 [82.9\%] versus 167 [50.0\%]), glucocorticoids (72 [87.8\%] versus 232 [69.5\%]) and intravenous immunoglobulin treatment (68 [82.9\%] versus $191[57.2 \%]))$ was also significantly higher in patients with heart disease than in patients without heart disease. In addition, patients with heart disease were 
more likely to have other complications than patients without heart disease; these include ARDS (48 [58.5\%] versus $49[14.7 \%])$, acute kidney injury (7 [8.5\%] versus 1 [0.3\%]), electrolyte disturbances (13 [15,9\%] versus 17 [5.1\%]), hypoproteinemia (11 [13.4\%] versus 16 [4.8\%]) and blood clotting disorders (6 [7.3\%] versus $6[1.8 \%])[17,19]$.

Thus, in the above studies, heart damage, advanced age, ethnicity, comorbid conditions, changes in laboratory parameters (leukocytes, C-reactive protein levels, procalcitonin, CPK$\mathrm{MB}$, myohemoglobin, N-terminal pro-B-type natriuretic peptide, aspartate aminotransferase and creatinine, CRP, procalcitonin, D-dimer, (PK-MB), characteristic radiological changes are a factor in the severe course of COVID-19, and is associated with a higher riskof nosocomial mortality.

The main causes of severe course and high mortality in COVID-19 are:

- The presence of various cardiac pathologies and heart damage in COVID-19;

- Old age as a risk factor;

- Ethnicity also mattered in severe illness;

- Comorbid conditions such as hypertension, diabetes mellitus, COPD, obstructive sleep apnea syndrome, bronchial asthma and "other pulmonary diseases" have been associated with an increased risk of ARDS;

- Laboratory parameters such as mean leukocyte count, levels of C-reactive protein, procalcitonin, CPK-MB, myohemoglobin, N-terminal pro-B natriuretic peptide, aspartate aminotransferase and creatinine, CRP, procalcitonin, D-dimer, CPK-MB are essential in patients with cardiovascular disease;
- Instrumental radiological findings such as bilateral pneumonia and multiple spotting and frosted glass increase the risk of death.

\section{REFERENCES}

1. Временные методические рекомендации по профилактике, диагностике, лечению и реабилитации при коронавирусной инфекции(COVID19). МЗ УзР Версия 8 (20.09.20)

2. Хуанг Ц., Ван И, Ли Х и др. Клинические особенности пациентов, инфицированных новым коронавирусом 2019 г., в Ухане, Китай. Lancet . 2020; 395 (10223): 497-506. DOI: 10.1016 / So140-6736 (20) 30183-5 PubMedGoogle ScholarCrossref

3. Ван А., Ху Б., Ху С. и др. Клинические характеристики 138 госпитализированных пациентов с пневмонией, инфицированной новым коронавирусом 2019 г., в Ухане, Китай. ЈАМА . Опубликовано онлайн 7 февраля 2020 г. doi: 10.1001 / jama.2020.1585 СтатьяPubMedGoogle Scholar

4. Маджид М, Соломон С, Вардени О. Клинический бюллетень АСС: сердечные последствия нового уханьского коронавируса (2019-nCoV). Опубликовано 13 февраля 2020 г. https://www.acc.org/latest-incardiology/articles/2020/02/13/12/42/accclinical-bulletin-focuses-on- сердечные последствия-коронавирус-2019-нков

5. Всемирная организация здоровья. Клиническое ведение тяжелой острой респираторной инфекции при подозрении на инфекцию, вызванную новым коронавирусом (nCoV): временное руководство.Опубликовано 28 января 2020г. 
The American Journal of Medical Sciences and Pharmaceutical Research

(ISSN - 2689-1026)

Published: October 20, 2021 | Pages: 12-17

IMPACT FACTOR

2021: 5.64

Doi: https://doi.org/10.37547/TAJMSPR/Volume03Issue10-02

OCLC - 1121105510

https://www.who.int/publications-

detail/clinical-management-of-severe-

acute-respiratory-infection-when-novel-

coronavirus-(ncov)- подозрение на

инфекцию

6. Раньери В.М., Рубенфельд Г.Д., Томпсон

Б.Т. $и$ Ар Синдром острого респираторного дистресс-синдрома.

JAMA . 2012; $307 \quad$ (23): 2526 2533.PubMedGoogle Scholar

7. Заболевание почек: улучшение глобальных результатов (KDIGO) Рабочая группа по острой травме почек. Руководство KDIGO по клинической практике при остром повреждении почек. Kidney Int Suppl . 2012; 2: 1.Google ScholarCrossref

8. Ван М., Ву Кью, Сюй В.3. и др. Клиническая диагностика 8274 образцов с коронавирусом нового типа 2019 года в Ухани. Опубликовано 2020 г. По состоянию на 12 марта 2020 r.https://www.medrxiv.org/content/10.1101 /2020.03.02.20030189v1.full.pdf

9. Guan WJ, Ni ZY, Hu Y и др. Клинические характеристики новой коронавирусной инфекции 2019 г. в Китае.Опубликовано 2020 г. По состоянию на 12 марта 2020 г.https://www.medrxiv.org/content/10.1101 /2020.02.06.20020974V1

10. Yu CM, Wong RS, Wu EB, et al. Сердечнососудистые осложнения тяжелого острого респираторного синдрома. Исследование уровня J Med . 2006; 82 (964): 140-144. DOI : 10.1136 / pgmj.2005.037515PubMedGoogle Scholar Crossref.

11. Альхогбани Т. Острый миокардит, связанный с новым коронавирусом ближневосточного респираторного синдрома. Ann Saudi Med . 2016; 36 (1): 78-80. DOI : 10.5144 / 0256-
4947.2016.78PubMedGoogle

ScholarCrossref

12. Ши С., Цинь М., Шен Б., Цай И, Лю Т., Ян Ф. и др. Ассоциация сердечной травмы и смертности среди госпитализированных пациентов с COVID-19 в Ухане, Китай. JAMA Cardiol. 2020 мap 25;

13. Ли Х, Сюй С, Ю М, Ван К., Тао И, Чжоу И и др. Факторы риска тяжести и смертности взрослых пациентов с COVID-19 в Ухани. J Allergy Clin Immunol.2020 Apr 12;

14. Wu C, Chen X, Cai Y, Zhou X, Xu S, Huang $H$ и др. Факторы риска, связанные с синдромом острого респираторного дистресса и смертью пациентов с коронавирусной болезнью 2019 Пневмония в Ухане, Китай. JАMA Intern Med.2020;

15. Дреер М., Керстен А., Бикенбах Дж., Бальфанц П., Хартманн Б., Корнелиссен С. и Ар. Характеристика 50 госпитализированных пациентов с COVID-19 с ОРДС и без (17.04.2020). Dtsch Ärztebl Int. 2020; (117): 271-8.

16. Би Кью, Хонг Ц., Мэн Дж., Ву 3., Чжоу П, Е 4 и др. Характеристика клинического прогрессирования COVID-19 среди пациентов в Шэньчжэне, Китай: наблюдательное когортное исследование. medRxiv. 202013 мая; 2020.04.22.20076190.

17. Lian J, Jin X, Hao S, Cai H, Zhang S, Zheng L и др. Анализ эпидемиологических и клинических особенностей у пожилых пациентов с коронавирусной болезнью 2019 (COVID-19) за пределами Ухани. Clin Infect Dis [Интернет]. [цитируется 5 мая 2020 г.]; Доступно по ссылке: http://academic.oup.com/cid/advancearticle/doi/10.1093/cid/ciaa242/5811557.

18. Лю Ю., Сунь В., Ли Дж., Чен Л., Ван Ю., Чжан Л. и др. Клинические особенности и 
прогрессирование синдрома острого респираторного дистресс-синдрома при коронавирусной болезни 2019. medRxiv. 202027 февраля; 2020.02.17.20024166.

19. Фадель Р., Моррисон А., Вахиа А., Смит 3. Р., Чаудри З., Бхаргава П. и др.Ранние короткие курсы кортикостероидов у госпитализированных пациентов с COVID-19. medRxiv. 20205 мая; 2020.05.04.20074609.

20. Rica R de la, Borges $M$, Aranda M, Castillo A del, Socias A, Payeras A, et al.Низкие уровни альбумина связаны с худшими результатами в серии случаев пациентов c COVID-19 в Испании: ретроспективное когортное исследование.medRxiv. 2020 11 мая; 2020.05.07.20094987.

21. Хан А., Чаттерджи А., Сингх С. Сопутствующие заболевания и различия в исходах COVID-19 среди афроамериканских и белых пациентов. medRxiv. $2020 \quad 15 \quad$ мая; 2020.05.10.20090167.

22. Чжан Пэн, Чжу Лихуа, Цай Цзинцзин, Лэй Фанг, Цинь Цзюань-Хуан, Се Цзин и др. Связь стационарного использования ингибиторов

ангиотензинпревращающего фермента и блокаторов рецепторов ангиотензина II со смертностью среди пациентов с гипертонией, госпитализированных с COVID-19. Circ Res [Интернет]. [цитируется 19 мая 2020 г.]; O (0). Доступно по ссылке: https://www.ahajournals.org/doi/10.1161/Cl RCRESAHA.120.317134.

23. Палайодимос Л., Коккинидис А.Г., Ли В., Караманис Д., Огнибене Дж., Арора С. и др. Тяжелое ожирение связано с более высокой госпитальной смертностью в когорте пациентов с COVID-19 в Бронксе,
Нью-Йорк. medRxiv. 20209 мая; 2020.05.05.20091983.

24. Ши Кью, Чжан Икс, Цзян Ф., Чжан Икс, Ху H, Биму С. и Ар. Клинические характеристики и факторы риска смертности пациентов с диабетом COVID-19 в Ухане, Китай: ретроспективное исследование с двумя центрами. Уход за диабетом. 202014 мая. 